\title{
O projeto iluminista escolar e sua incompatibilidade com a sociedade contemporânea hiperativa
}

SIBILIA, P.

Redes ou Paredes.

A escola em tempos de dispersão.

Rio de Janeiro: Contraponto, 224 p., 2012.



Resumo: O que é a escola, e para que serve a instituição? Esta é a premissa do livro Redes ou Paredes - A escola em tempos de dispersão, de Paula Sibilia, que se debruça ao trajeto antropológico da criação da escola, desde sua origem no projeto iluminista, até os tempos de hoje, em um mundo em rede e dispersivo. A pesquisadora se concentra na crise escolar e da instituição e comenta possibilidades para seu futuro frente a uma mudança de subjetividade na sociedade contemporânea hiperativa.

Palavras-chave: escola, dispersão, rede, subjetividade

Abstract: The Enlightenment project and its incompatibility with today's hyperactive society - What is school and what is the role of this institution? That is the main premise of Paula Sibilia's book Redes ou Paredes - A escola em tempos de dispersão (Networks or Walls - The school in times of dispersion), which examines the anthropological journey of the emergence of schools, from the age of Enlightenment to the interconnected and dispersive world of today. The researcher focuses on the crisis the institution faces and discusses prospects for its future in response to a change in the subjectiveness of today's hyperactive society.

Keywords: school; dispersion; network; subjectivity 
Em Redes ou Paredes - A escola em tempos de dispersão, a pesquisadora Paula Sibilia se debruça no estudo da instituição escolar e explana a sua crise na contemporaneidade. Para tal, no tocante à estrutura capitular, o livro realiza um percurso antropológico da escola: torna inteligível o trajeto desde a criação das escolas, até a decadência atual deste modelo, bem como aponta o impacto das mídias eletrônicas no âmbito escolar.

Sibilia tem como ponto de partida a questão da criação de uma subjetividade disciplinada pela instituição. O projeto iluminista de educação acreditava em um sistema coercitivo, em que era necessário domar as mentes e os corpos das crianças com a finalidade de se tornarem trabalhadores ativos em uma sociedade industrial e sujeitos bem enquadrados e seguidores das leis do Estado. Assim, a escola surgiu como instituição que deveria não somente ensinar as regras da sociedade para os futuros adultos, bem como modelar corpos preparados para encaixarem-se nas linhas de montagem das indústrias. Para a autora, contudo, o Estado vem perdendo sua capacidade de imprimir significado à escola, já que o eixo da subjetividade mudou, foi deslocado, assim como as necessidades do mercado. A própria escola tem uma aparelhagem incompatível com a subjetividade atual das crianças.

As mesmas crianças de outrora, enviadas para a escola para serem esculpidas em cidadãos, hoje são definidas por diversos outros elementos, além de serem consumidores que o mercado pretende agradar e estimular. Aliado a isto, as novas tecnologias de comunicação, como os dispositivos móveis de acesso à rede, também acarretam uma mudança de paradigma em termos de estilo de vida e criação de subjetividades. A autora coloca que com a mudança nos vetores socioculturais, econômicos e políticos, mudam também os indivíduos e os corpos. E questiona: para que serve a escola? A questão no âmbito iluminista pode ser respondida historicamente, mas não dá conta do sujeito da contemporaneidade. Portanto, de que tipo de escola precisamos?

Na trama da definição da instituição escolar, Sibilia aponta que sua capacidade de adaptação aos novos fenômenos é limitada, e que sua eficácia e sentido podem ser perdidos para as futuras gerações. Assim como não existiam no passado, as escolas podem desaparecer, ou serem redefinidas radicalmente.

Uma das respostas possíveis para a instituição é a informatização de seus processos. Porém, a pesquisadora ressalta que a incorporação de tecnologia é importante, mas não deve resolver os conflitos, visto que o uso de computadores nas aulas tende a se apresentar como panaceia. Os aparelhos de informatização não são neutros, mas carregados de valores, alguns não compatíveis com a própria instituição, por subverterem o regulamento básico da escola: a questão das paredes. É impossível confinar os dispositivos móveis em espaço e tempo; regular estas duas dimensões é papel da escola. Se todos os alunos podem se conectarem à rede, cada qual a seu tempo, não seriam mais necessárias quatro paredes.

Ademais, há o risco de estes aparelhos se tornarem agentes de dispersão, sendo importante primeiramente voltar a atenção dos alunos para a aprendizagem, em um novo tipo de projeto pedagógico. Sibilia também coloca em pauta a necessidade dos alunos de aulas divertidas, e aponta como isto é uma mudança importante, já que, anteriormente, 
a emancipação deveria acontecer pelo conhecimento. Isto é, em decorrência de espetacularização das relações sociais, a escola poderia repetir o mesmo modelo, de maneira que as aulas sejam mais espetáculo do que educação.

Outro paradigma abordado é o da indistinção gradual entre esfera pública e esfera privada, que tende a ocorrer por conta da crise da estrutura familiar, aliado ao projeto iluminista da escola. Assim que a família coloca nas mãos da escola o papel de civilizar os alunos, a hierarquia familiar confundiu-se paulatinamente com a da instituição, em que o aluno se vê como filho, e a escola se torna uma extensão da sua casa. Se a escola foi criada também para atender a demandas do mercado, esta esfera atende a signos que exigem pouca reflexão, e muita atenção para o consumo. A diferença é que a escola de hoje não cria cidadãos para um mundo que necessita de trabalhadores da indústria, mas quer oferecer serviços a consumidores. Um potencial desdobramento seria que o mercado assumisse, por fim, o papel que era do Estado, também na escola. Esta mudança, para a pesquisadora, ocorreria de forma sutil, contudo, real, de modo que a instituição pode vir não servir à subjetividade atual, e também não cumprir o papel para que foi criada.

Paula Sibilia propõe, por fim, o diálogo, ao invés do ensino como conhecemos. Para a autora, isso aconteceria quando ensinarmos os alunos a pensar, não somente a usar de técnicas e tecnologias, ou nem mesmo compreender informação. Para a pesquisadora, uma das lições mais importantes seria de navegar e realizar uma curadoria para a quantidade massiva de informação que recebemos. Uma resposta possível está em encontrar o balanceamento entre receber a informação e analisar, sem ficarmos isolados das opiniões dos outros, mas também sem ficarmos dispersos pelo seu contingente.

A função de Redes ou Paredes - A escola em tempos de dispersão é a de questionar não somente a estrutura escolar, mas o tipo de pessoa que gostaríamos de formar em nossas escolas, quais são as possibilidades e maneiras de assimilar as novas subjetividades no âmbito educacional e, também, o que é educar em um contexto mais geral. Dessa maneira, o livro contribui para uma discussão que só poderia ser gerada pela crise, e investiga a intuição em seu passado e presente, colocando-a sob um viés de uma contemporaneidade contraditória, em que é necessário domar corpos e mentes em uma sociedade hiperativa e multifacetada.

Flávia Tavares Gasi é doutoranda no PPG Comunicação e Semiótica da PUC-SP; é jornalista especializada em videogames e cultura pop.

flaviagasi@gmail.com 